\title{
Physicochemical evolution and evaluation of groundwater quality in Mougheul area (Southwest of Algeria)
}

\author{
Saliha Mebarki ${ }^{1}\left[\right.$ Benali Kharroubi ${ }^{1} \cdot$ Mohammed Amin Kendouci $^{2}$
}

Received: 3 January 2020 / Accepted: 18 January 2021 / Published online: 1 February 2021

(c) The Author(s) 2021

\begin{abstract}
In arid areas, the pressure on water resources and in particular on groundwater resources is on the rise, mainly due to increasing demand and the deterioration of water quality. In this context, the present work aims to follow the annual evolution, between 2009 and 2019 of the physicochemical parameters, and to evaluate the quality of groundwater of the region of Mougheul, by determining the data of $\mathrm{pH}$, TDS, conductivity and the concentrations of major ions $\left(\mathrm{Ca}^{+2}, \mathrm{Mg}^{+2}, \mathrm{Na}^{+}, \mathrm{K}^{+}\right.$, $\mathrm{Cl}^{-}, \mathrm{HCO}_{3}^{-}, \mathrm{SO}_{4}{ }^{-2}, \mathrm{NO}_{3}{ }^{-}$) of 07 water points. The results revealed that all the levels of the physicochemical parameters do not exceed the WHO potability standards, except high values were observed at the level of well W6 which exceeds the limits recommended by the WHO (50 mg /). The diagram of Schöeller and Berkaloff shows that the groundwater has the bicarbonate magnesium facies. The representation of the data on the Piper triangular diagram shows that W6 has the facies chlorinated and calcium sulfate and magnesium and the other water points have the facies bicarbonate calcium and magnesium. SAR values show that the groundwater of Mougheul is excellent for irrigation. The classification according to the Wilcox diagram shows that the groundwater of Mougheul in general is good quality, but the well of W6 water is suitable for irrigation and requires monitoring the evolution of salinity.
\end{abstract}

Keywords Southwestern algeria $\cdot$ Groundwater $\cdot$ Physicochemical parameters $\cdot$ Evolution $\cdot$ Irrigation $\cdot$ SAR

\section{Introduction}

In many parts of the world watersheds, river, ponds, aquifers and the associated ecosystems have undergone significant modifications; hence, the vitality, quality and availability of the water resources have been facing further human threats (Singh et al. 2015). In the present scenarios, many countries are facing the problem of water scarcity, even the good quality of drinking water is not available for the human society (Gleick 2000). Increasing water demand has forced people to depend on groundwater resulting in high water extraction from groundwater reserves (Singh et al. 2006; Thakur et al. 2013). The good quality of groundwater is important for future planning and management (Rawat et al 2018).

Saliha Mebarki

saliha.mebarki@yahoo.fr

1 Department of Hydraulic, University of Science and Technology Oran -Mohamed Boudiaf Oran, Bir El Djir, Algeria

2 Department of Civil Engineering and Hydraulic, University of Tahri Mohammed Bechar, Béchar, Algeria
To meet the satisfaction of drinking water needs, for the city of Bechar, located in southwest Algeria (Kendouci et al. 2019), technicians and decision makers have sought other additional water resources, namely in the Jurassic aquifer of Mougheul which located at the level of the North Ksour of the wilaya of Bechar. The objective of this work is to assess the physicochemical quality of groundwater in the Mougheul area. To do this, a sampling campaign was undertaken during the years 2009 until 2019. The physicochemical parameters measured in situ and at the laboratory were used to characterize these waters. The results were determined and evaluated the quality of water intended for human consumption (WHO standards) and for agricultural activities.

\section{Material and methods}

\section{Study zone}

Mougheul is located about $50 \mathrm{~km}$ North of the capital of the wilaya of Bechar (Fig. 1). It constitutes with the villages of Boukaïs and El Ahmar, what is commonly called the ksour of the North. It is a peaceful oasis, which rises in the

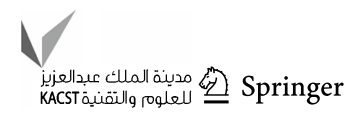



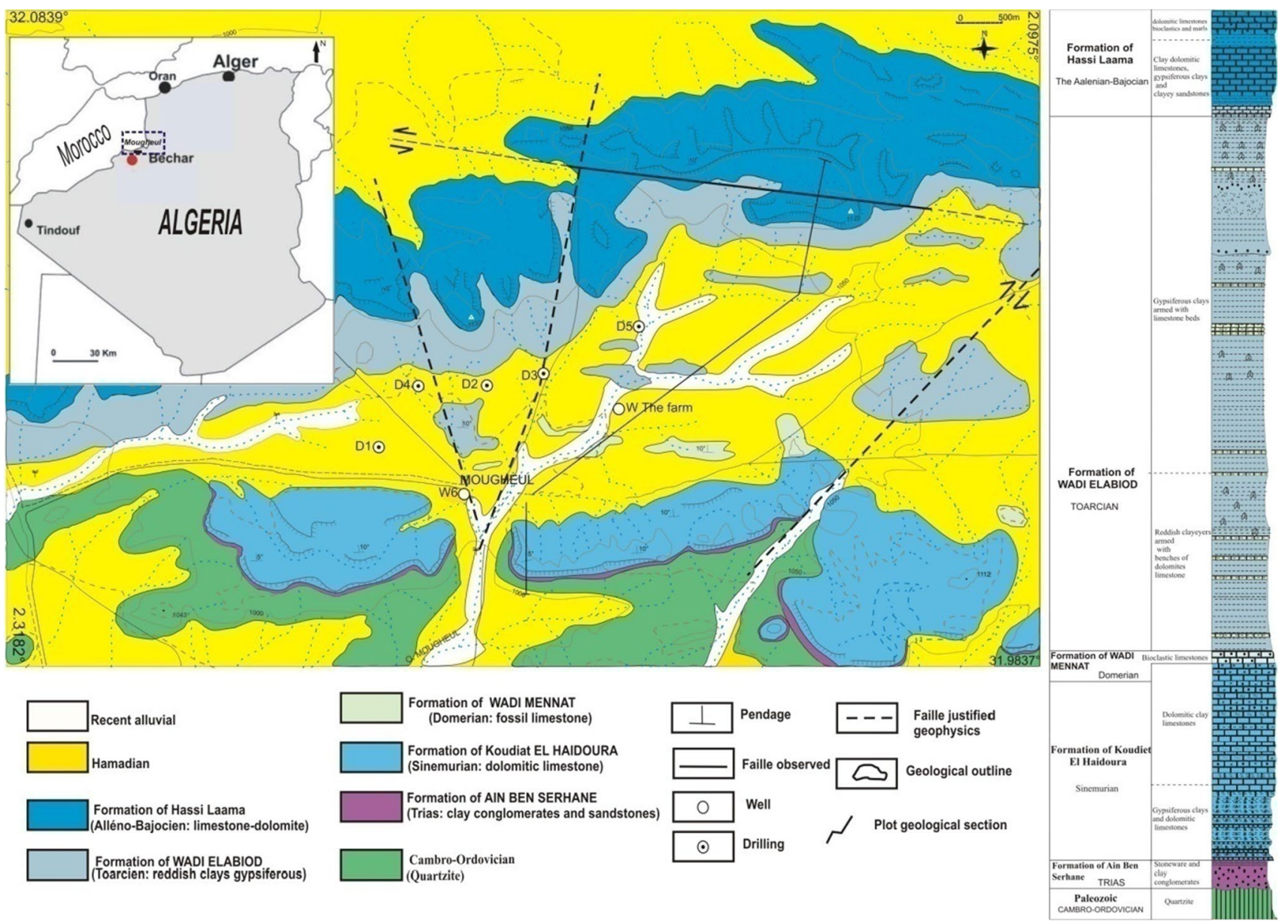

Fig. 1 Location map of the study area showing the sampling sites

southwest end of the Saharan Atlas. The study region is distinguished by its arid climate, and the harshness of the climate is due to its location in the extreme southwest of Djebel Grouz, to the orientation of the reliefs which are arranged in a general east-west direction. This arrangement allows the region to receive the humid currents of the West, but also the arid Saharan currents coming from the Southeast.

\section{Geology of the study area}

The Mougheul region is landlocked in the extreme southwest of Djebel Grouz. The latter is characterized by the presence of a pleated Paleozoic base and a powerful Jurassic cover of calcaro-dolomitic nature, at the limits of the study site, we know the following fields: paleozoic substrate. It constitutes the southern reverse of the small cuestas of Mougheul (Zerrouki 1993). It is an uneven alternation of shale sandstone and quartzite (Fig. 1). These lands are attributed to the Cambro-Ordovician (Chabane et al. 2019). Triaso-Jurassic cover: Five formations defined by their lithological content were recognized on the study site (Fig. 1). These formations cover an interval which extends from the Triassic to the AenoBajocian (Mekkaoui 2000; Nedjari et al. 2002); the age of the formations is determined by their content in Brachiopods and by analogy with the neighboring regions.

Formation of Aïn Ben Serhane: It outcrops by binding around the southern reliefs of the Mougheul region. This training is discordant on the Cambro-Ordovician (Fig. 1), and it is attributed by analogy to the Triassic (Mekkaoui 2000; Mebarki 2013) admitting the following subdivisions: 1 / Lower limb (3 m): It is made up of heterogeneous conglomerates, with medium, angular pebbles, rarely rounded. They are mainly composed of pebbles of quartzites, sandstones and andesites. 2 / Upper limb (1 m):A / Lower term (0.5 m): It includes reddish clay sandstones in small regular banks. B / Upper term $(0.5 \mathrm{~m})$ : corresponds to reddish silty clays.

Formation of Koudiat El Haïdoura $(64 \mathrm{~m})$ It constitutes the southern cuestas of the Mougheul region. It is essentially a limestone-dolomitic formation (Nedjari et al. 2002). By its position between the Domérien and the Triassic, this formation is attributed to the Sinemurian (Deleau 1952). It is subdivided from bottom to top: 1 / Lower limb (29 m): A 
/ Term 1 (6 m): This term begins with versicolored gypsiferous clays, admitting dolomitic intercalations in a plate; they are capped with a gray bar of vacuolar dolomite. B / Term 2 $(15 \mathrm{~m})$ : These are gypsum marls, admitting benches of solid gypsum and benches of clay dolomite. C / Term 3 (8 m): It represents the first carbonates which succeed the underlying gypsum marls. The first bench ravines the marl. It consists of clay dolomitic limestones, passing upward to dolomitized limestones in $0.5-\mathrm{m}$ medium beds, with beige patina and whitish break. This term ends with dolomites. 2 / Upper limb (35 m): A / Term 1 (7.5 m): These are dolomitic clay limestones in small benches, followed by dolomitic bars, and dolomitic limestones. B / Term 2 (3 m): It begins with dolomitic bars and dolomitic limestones. C/ Term 3 (21 m): This term includes dolomites in vacuolar metric bars, surmounted by dolomitic limestones. In its upper part, we observe dolomites, and dolomitic limestones, and end with a limestone. $\mathrm{D} /$ Term $4(8 \mathrm{~m})$ : Dolomites in small benches, and bars of dolomites.

Formation of Wadi Mennat $(5 \mathrm{~m})$ It is not flush with the boundaries of the study site; small scattered outcrops appear that and the favor of the notches of the wadis. Taking into account the quality of outcrop, we only see the upper part of this formation represented by bioclastic dolomitic limestones of beige to reddish color, and this formation contains brachiopods making it possible to fix its age at the Domérien (Nedjari et al. 2002).

Formation of Wadi El Abiod $(120 \mathrm{~m})$ The red clays form the Mougheul plain, with many gaps in visibility. The lower and middle limbs are not distinguished here because of the fairly unfavorable outcrop conditions. Its lower limit is also masked by recent deposits. In general, reddish clay-gypsum formations are observed. By comparison, and analogy, this sebkha-like formation is attributed to the regressive Toarcian of the Atlas domain (Mekkaoui 2000; Mebarki 2013).

Formation of Hassi Laâma $(34 \mathrm{~m})$ This formation constitutes the northern reliefs of Mougheul (Figure 2). By the brachiopods they contain, this formation is attributed to the Aaleo-Bajocien (Nedjari et al. 2002).

It consists of: 1 / Lower limb (18.5 m): A / Term 1 (3 m): It is represented by clay dolomitic limestones, gullying the underlying gypsum clays. They are surmounted by red clayey sandstones. B / Term 2 (15.5 m): This term begins with a medium bank of bluish limestones, followed by dolomitic limestones in small patches, beige with a patina, and whitish with a break. The whole is surmounted by dolomites in metric benches.

2 / Upper limb (15.5 m), A / Term 1 (2.5 m): These are beige marls, B / Term $2(8 \mathrm{~m})$ : These are dolomitic limestones, C / Term $3(5 \mathrm{~m})$ : It is represented by dolomitic limestones.

The Quaternary can be subdivided into: 1 / Old alluviums: They are represented by silty deposits of sandy-silty gravel or pebbles blunt with limestones and quaternaries. They are consolidated and closely linked to the old terraces of the wadis. 2 / Recent alluviums: They are closely linked to the main wadis in the region, they are gravel sand, and black blocks consolidated in places they are peaty and clayey (Mekkaoui 2000; Mebarki 2013).

\section{Hydrogeology of the Study Area}

The essential element of the whole hydrogeological unit of the Mougheul basin is the aquifer of the dolomitic limestones of the lower Jurassic whose formations outcrop widely in the North at the level of the Djebel Grouz. The Mougheul aquifer is a semi-captive aquifer with an average thickness of $64 \mathrm{~m}$ contained in the very cracked dolomitic limestones of the Lower Jurassic of the Koudiat El Haïdoura formation (Agence Nationale des Ressources Hydrauliques: National Water Resources Agency, 2008). It is the most important permeable base of the entire system in this region and even in the northern part of Bechar. These very extensive outcrops give this aquifer system a vast impluvium implying a certain recharge of the underground resource. The direct feeding is done by its impluvium whose surface of outcrop is very wide in space (Deleau 1952; Roche 1973; Idrotecneco, 1979).

\section{Sampling and analytical methods}

Groundwater quality has multi-dimensional facets that are very important elements of water resources (Srivastava et al. 2008, 2012; Singh et al. 2012). Hence, monitoring and conserving surface and groundwater resources are very much required for sustainable environment and to fulfill the freshwater demand (Sun et al. 1992). In order to highlight and assess the physicochemical quality of groundwater of Mougheul area, a sampling network of 07 water points has been set up to allow data collection. These samples for physicochemical analyses were carried out in the last years 2009-2019. The methods described by (Rodier, 1996) were followed during field and laboratory work. The goal was to ensure that the water samples truly represented the properties and conditions of the subsurface environment. Water was pumped from the well until the temperature, EC, and $\mathrm{pH}$ became constant. The collected samples were analyzed for major cations, anions, and TDS. Concentrations of $\mathrm{Na}^{+}$ and $\mathrm{K}^{+}$were determined using a flame photometer. As for $\mathrm{Ca}^{2+}, \mathrm{Mg}^{2+}, \mathrm{HCO}_{3}^{-}$, and $\mathrm{Cl}^{-}$concentrations, these were determined by volumetric titration method, and $\mathrm{SO}_{4}{ }^{-2}$ and $\mathrm{NO}_{3}{ }^{-}$spectrophotometrically (kendouci et al. 2016). The calculation of the ion equilibrium error is evaluated by taking the relationship between the total cations and the total anions for each sample of water. It is recognized that the anion-cation balance is less than $\pm 5 \%$ (Domenico et al, 1997). The geographic coordinates (X, Y, Z) of each water

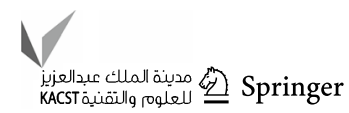


point were measured using a GPS (Global Positioning System) (Table 1).

\section{Results and discussion}

\section{Chemical facies of groundwater}

The purpose of interpreting the results of the analyzes is to determine the chemical facies and to perform a spatiotemporal comparison. Among the most used graphic methods, that of Schöeller and Berkaloff (1935-1938). According to the diagram of Schöeller and Berkaloff in the year 2009

Table1 Characterization of the sampling locations

\begin{tabular}{lllll}
\hline water point & latitudes & Longitude & Altitude $(\mathrm{m})$ & Depth $(\mathrm{m})$ \\
\hline D1 & $32^{\circ} 01^{\prime} 38^{\prime \prime} \mathrm{N}$ & $02^{\circ} 13^{\prime} 57^{\prime \prime} \mathrm{W}$ & 1026 & 150 \\
D2 & $32^{\circ} 01^{\prime} 51^{\prime \prime} \mathrm{N}$ & $02^{\circ} 12^{\prime} 53^{\prime \prime} \mathrm{W}$ & 1032 & 152 \\
D3 & $32^{\circ} 01^{\prime} 59^{\prime \prime} \mathrm{N}$ & $02^{\circ} 12^{\prime} 26^{\prime \prime} \mathrm{W}$ & 1034 & 175 \\
D4 & $32^{\circ} 01^{\prime} 57^{\prime \prime} \mathrm{N}$ & $02^{\circ} 13^{\prime} 29^{\prime \prime} \mathrm{W}$ & 1033 & 200 \\
D5 & $32^{\circ} 02^{\prime} 12^{\prime \prime} \mathrm{N}$ & $02^{\circ} 11^{\prime} 32^{\prime \prime} \mathrm{W}$ & 1044 & 150 \\
W6 & $32^{\circ} 01^{\prime} 16 " \mathrm{~N}$ & $02^{\circ} 13^{\prime} 13^{\prime \prime} \mathrm{W}$ & 1023 & 15.6 \\
W the Farm & $32^{\circ} 01^{\prime} 54^{\prime \prime} \mathrm{N}$ & $02^{\circ} 11^{\prime} 46^{\prime \prime} \mathrm{W}$ & 1033 & 20 \\
\hline
\end{tabular}

(Fig. 2a), we have found that: The drilling waters D5 have the bicarbonate calcium facies. The other water points have the bicarbonate magnesian facies. For the samples of the 2019 companion (Fig. 2b), there is a notable variation for drilling D5 which takes the bicarbonate magnesium facies.

The Piper's trilinear diagram includes three triangles (Back and Hanshaw 1965) have defined the subdivisions of the diamond field that have represented water type or categories that form the basis for one common classification scheme for natural waters. Lithology, solution kinetics, and flow patterns of the aquifer control hydrochemistry of any facies (Nemčić-Juree et al. 2017).

The representation of the data on the triangular Piper diagram of the companions 2009 and 2019 (Fig. 3), shows that: W6 well water has the facies chlorinated and calcium and magnesium sulfate, and the other water points have the bicarbonate calcium and magnesium facies.

\section{Irrigation water quality}

Groundwater has become the major source of water use in the agricultural sector in many countries where river and drainage systems are not sufficient. Therefore, poor groundwater quality for irrigation purpose is a matter of worry in recent years (Rawat et al 2018).

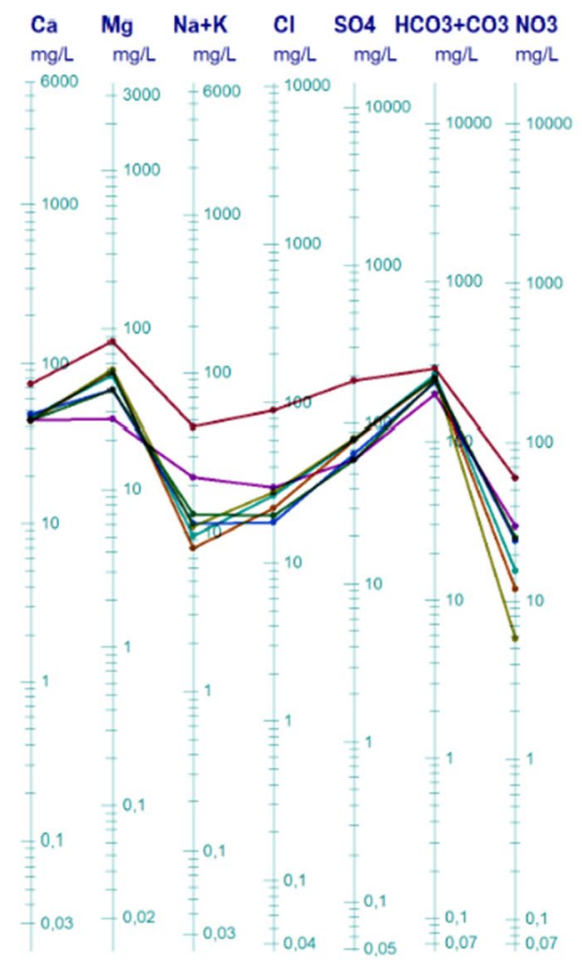

(a)

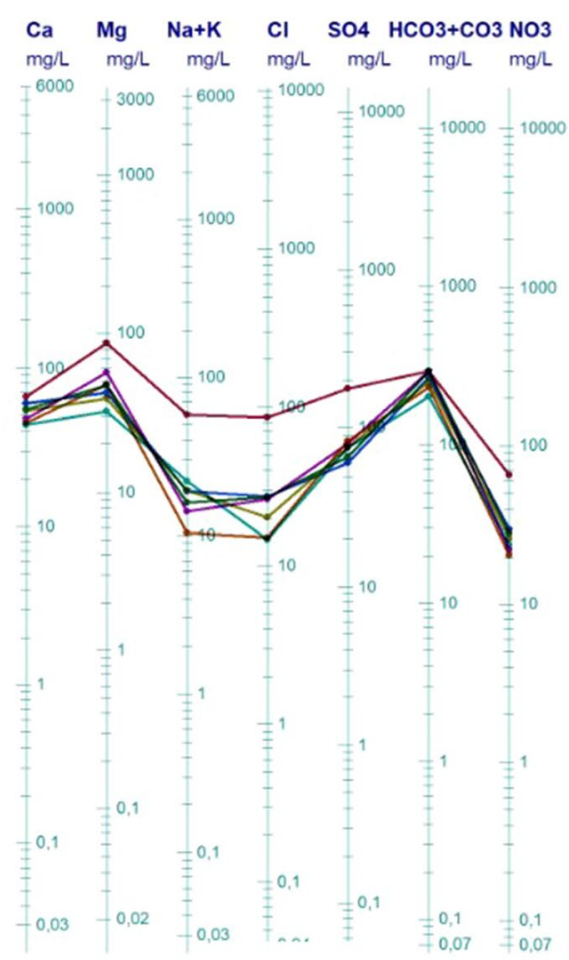

(b)

Fig. 2 Schöeller-Berkaloff analysis diagram for 2009 and 2019, using the Diagram software of the Avignon Hydrogeology Laboratory (Roland Simler 2003-2019) version 6.6 

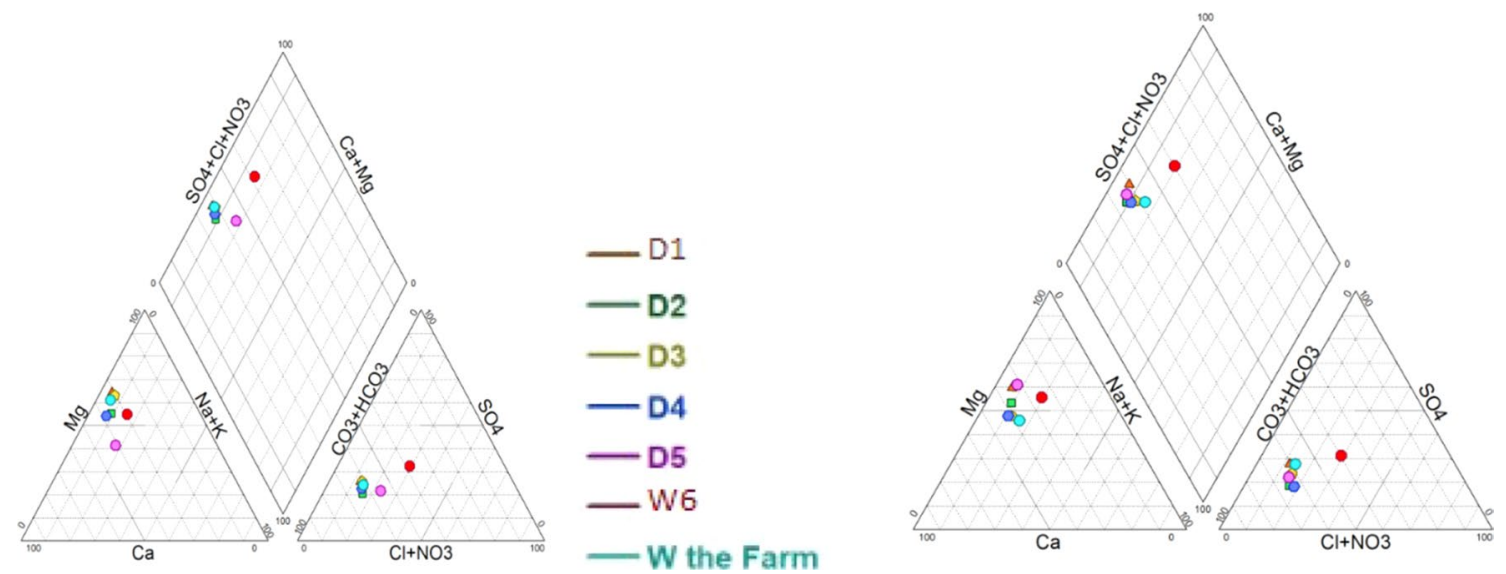

Fig. 3 Piper triangular diagram period 2009 and 2019, using the Diagram software of the Avignon Hydrogeology Laboratory (Roland Simler 2003-2019) version 6.6

The study area is characterized by a dry climate, where salinization and alkalinization of water are the main risks that may be associated with irrigation water. To classify the irrigation water, the classification will be used from SAR.

\section{Classification according to Sodium adsorbed by the soils "SAR"}

This classification requires an assessment of the concentration of $\mathrm{Na}^{+}$ions in soil, which replaces calcium or magnesium in the complex by following relationship Eq. (1) (Appelo et al. 1993; Batram et al. 1999):

$\mathrm{SAR}=\mathrm{Na}^{+} /\left[\left(\mathrm{Ca}^{+2}+\mathrm{Mg}^{+2}\right) / 2\right]^{1 / 2}$

where

Concentrations of $\mathrm{Na}^{+}, \mathrm{Ca}^{+2}$ and $\mathrm{Mg}^{+2}$ ions are expressed in $\mathrm{meq} / \mathrm{l}$.

On the basis of SAR range, irrigation water can be classified into four classes as SAR $<10$ (ideal or excellent), 10-18 (good), 18-26 (doubtful) and $>26$ (unsuitable).

The SAR values for the waters of the Mougheul area are less than 10; therefore, the quality of the water intended for irrigation is excellent (Table 2). The quality of irrigation water is not determined solely by the SAR of the water but also by the effects of evapotranspiration on the increase in the concentration of ions and the phenomena of precipitation of calcite (Appelo et al. 1993).

\section{Exchangeable sodium percentage (ESP)}

The percentage of Na has been calculated using Eq. (2).

$$
\mathrm{ESP}=\left[\mathrm{Na}^{+} /\left(\mathrm{Ca}^{+2}+\mathrm{Mg}^{+2}+\mathrm{Na}^{+}+\mathrm{K}^{+}\right)\right] \times 100
$$

where all the concentration units are in meq/l. The sodium reacts with soil to reduce its permeability; higher amount of sodium in water has reduced crop yield. Wilcox 1955 has used ESP and EC to classify groundwater and divided into five categories. It is recommended that the ESP should not exceed $60 \%$ in water which is used for irrigation purposes (Nemčić-Juree et al, 2017). All the Mougheul water samples have low concentration of $\mathrm{Na} \%$ and fall in excellent to good category, and the water of the well W6 lies in the category of good to permissible (Fig. 4). Hence, generally water is suitable for agriculture application.

\section{Physical parameters}

\section{Temperature}

Temperature plays a major role in the solubility of salts and gases and thus in conductibility. It differentiates between water that circulates deep and water that circulates near the surface, one of the factors affecting the speed of chemical reactions. The average water temperature in all the seasons was ranging from $24{ }^{\circ} \mathrm{C}$ to $25^{\circ} \mathrm{C}$; the thermal variation of
Table 2 Alkalinity hazard classes of groundwater, the Mougheul area

\begin{tabular}{|c|c|c|c|c|c|c|c|}
\hline SAR & D1 & D2 & D3 & D4 & D5 & W6 & W the farm \\
\hline Max (year) & $2.88(2015)$ & 1.99 (2019) & $2.56(2018)$ & $2.24(2018)$ & 3.35 (2009) & 6.42 (2019) & 3.45 (2019) \\
\hline Min (year) & $1.00(2009)$ & $1.50(2011)$ & $1.42(2009)$ & 1.15 (2010) & $1.26(2014)$ & 4.83 (2009) & $1.00(2013)$ \\
\hline Water class & Excellent & Excellent & Excellent & Excellent & Excellent & Excellent & Excellent \\
\hline
\end{tabular}



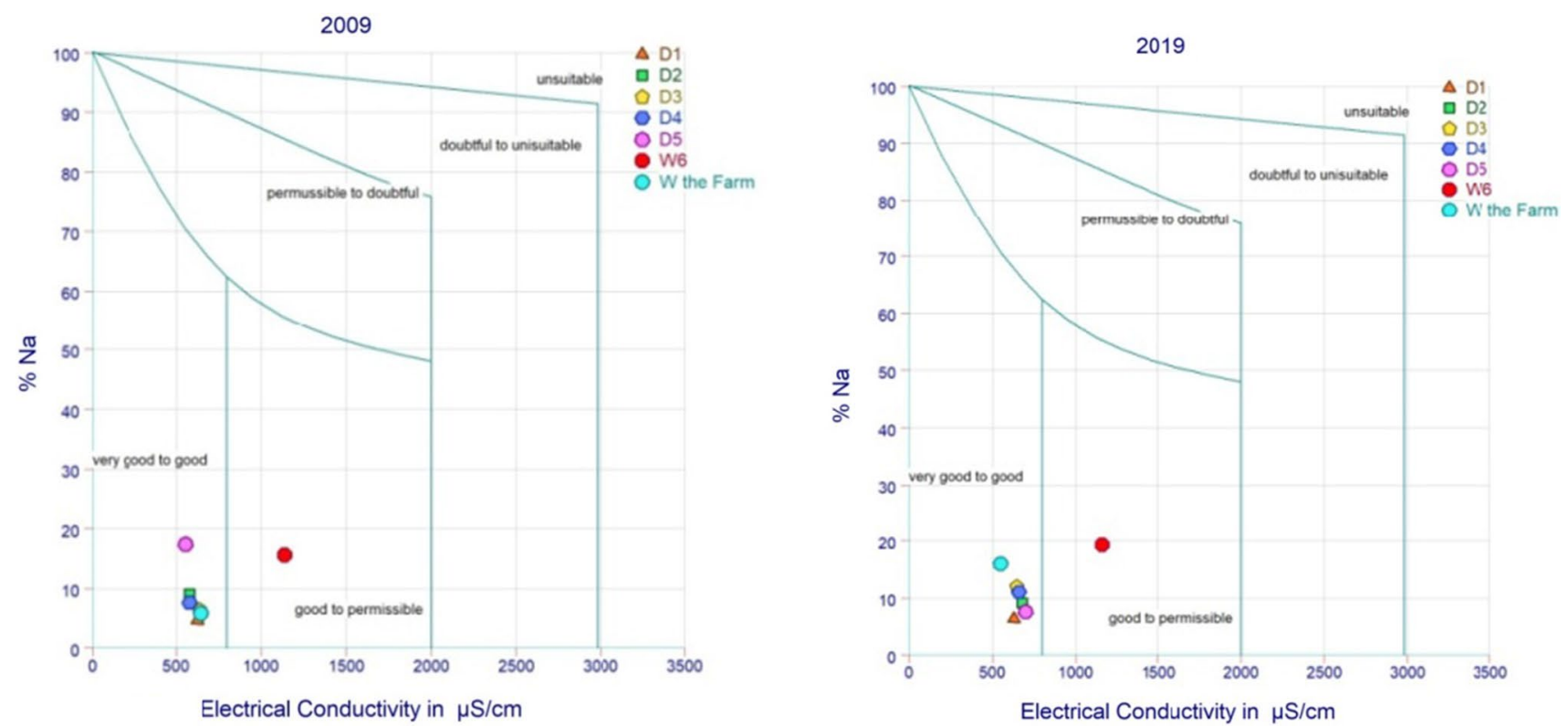

Fig. 4 Illustration of ESP of groundwater samples of the Mougheul area (2009-2019), using the Diagram software of the Avignon Hydrogeology Laboratory (Roland Simler 2003-2019) version 6.6

groundwater may be related to the depth of the aquifer and the season. For example, the former Council of the European Communities directives set $12{ }^{\circ} \mathrm{C}$ as the guide level for the temperature of the intended water (human consumption, and at $25{ }^{\circ} \mathrm{C}$, the temperature not to exceed (Rodier 2009)).

\section{Hydrogen potential $(\mathrm{pH})$}

The $\mathrm{pH}$ of water is defined according to its concentration of $\mathrm{H}^{+}$ions contained in the solution. $\mathrm{pH}$ is an important parameter that determines water suitability for human use, agriculture, industrial applications, and aquatic ecosystem functioning (Sharma et al. 2018). The hydrogen potential of water represents its acidity or alkalinity linked to the nature of the terrain crossed (Rodier 2009). Even though no health-based guideline occurs for $\mathrm{pH}$ (Thakur et al. 2015), values obtained for each of the samples fall under an optimum range of $6.98-7.8$ (Table 3 ). The $\mathrm{Ph}$ is of major importance in determining the corrosivity of water (Thakur et al. 2015).

According to Fig. 5, we notice variations in percentage decreases by contribution to 2009 which may reach $8 \%$ (2014 and 2019). The World Health Organization (WHO) specifies a value of 6.5-8.5, so our samples are in accordance with the quality for water supply and agricultural use.

\section{Electric conductivity (EC)}

EC is a measure of water capacity to convey electric current (Rawat et al. 2012, 2013). It is used to estimate the amount
Table $3 \mathrm{pH}$ values of water points in the Mougheul area (2009-2019)

\begin{tabular}{llllllll}
\hline Years & D1 & D2 & D3 & D4 & D5 & W6 & W the farm \\
\hline 2009 & 7.49 & 7.49 & 7.17 & 7.06 & 7.12 & 7.50 & 6.98 \\
2010 & 7.45 & 7.20 & 7.18 & 7.10 & 7.20 & 7.62 & 7.00 \\
2011 & 7.44 & 7.03 & 7.20 & 7.50 & 7.36 & 7.48 & 7.30 \\
2012 & 7.40 & 7.02 & 7.30 & 7.50 & 7.30 & 7.48 & 7.00 \\
2013 & 7.35 & 7.01 & 7.80 & 7.64 & 7.28 & 7.45 & 6.92 \\
2014 & 7.35 & 7.01 & 7.50 & 7.50 & 7.30 & 7.50 & 6.95 \\
2015 & 7.20 & 7.02 & 7.50 & 7.40 & 7.35 & 7.55 & 6.95 \\
2016 & 7.01 & 7.03 & 7.60 & 7.30 & 7.40 & 7.62 & 6.94 \\
2017 & 7.15 & 7.10 & 7.50 & 7.40 & 7.38 & 7.60 & 6.98 \\
2018 & 7.20 & 7.20 & 7.60 & 7.45 & 7.36 & 7.60 & 7.00 \\
2019 & 7.36 & 7.38 & 7.70 & 7.45 & 7.30 & 7.59 & 7.10 \\
\hline
\end{tabular}




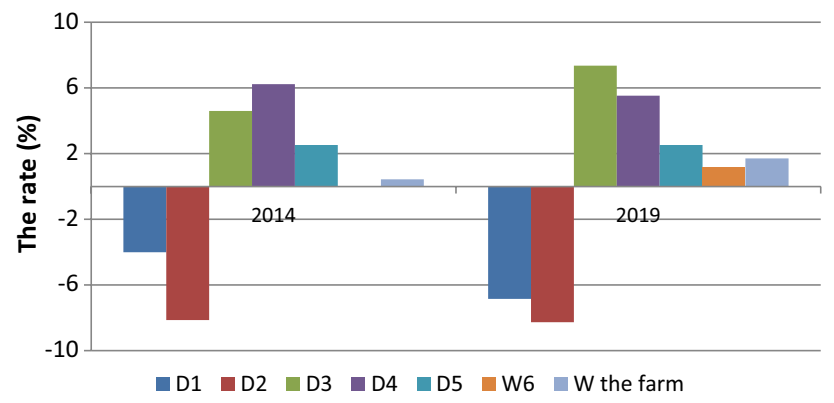

Fig. 5 The rate of change in pH between 2014 and 2019

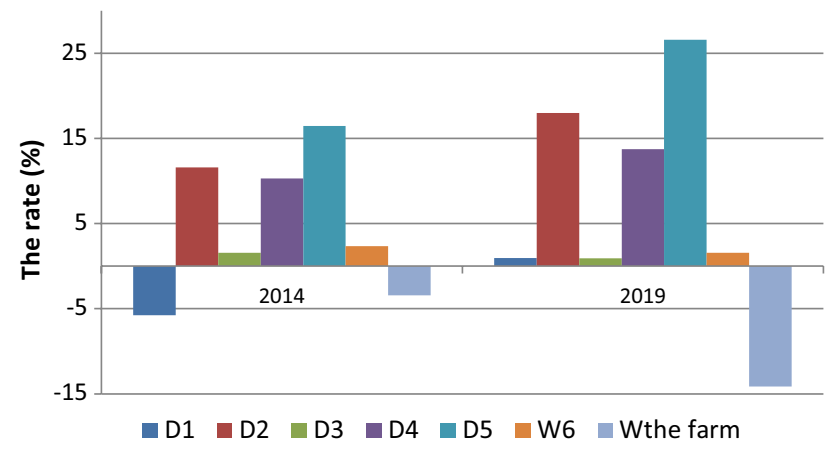

Fig.6 The rate of change in conductivity between 2014 and 2019

of dissolved solids. It increases as the amount of dissolved mineral (ions) increases. It is used as a basic index to select the suitability of water for agricultural purposes (Jacintha et al. 2016). For all samples, the conductivity is between 522 and $1198 \mu \mathrm{S} / \mathrm{cm}$ (Table 4). In addition to the WHO standard, the results obtained are lower than the standards (2700 $\mu$ s/ $\mathrm{cm}$ ) for the conductivity of drinking water.

The Fig. 6 shows that in 2014 the rate of increase in conductivity reached $16.45 \%$ in drilling D5 and a decrease of $5.76 \%$ in D1 drilling. In 2019 the maximum rate of increase recorded in the D5 drilling (26.58\%) and a strong decrease in the $w$ the farm $(14.15 \%)$.

\section{Total dissolved salt content (TDS)}

Total dissolved solids are an important parameter for assessing groundwater quality, and the term is used to describe the inorganic salts and small amounts of organic matter present in solution in water. The principal constituents are usually calcium, magnesium, sodium, and potassium cations and carbonate, bicarbonate, chloride, sulfate, and nitrate anions (Jacintha et al. 2016). High TDS levels typically indicate hard water and may lead to scale buildup in pipes, reduced efficiency of water filters, hot water heaters, etc., and aesthetic problems such as a bitter or salty taste (WHO 1993).

Other parameters (such as evaporation and evapotranspiration) can increase these concentrations. "The TDS is equal to the sum of the major ions contained in a liter of water" (Drever 2001). According to (Table 5) and the classification of Drever 2001, it can be said that the water at each water level is fresh.

Figure 7 shows that in 2014 the rate of increase in TDS reached $14.61 \%$ in drilling D5 and a decrease of $5.13 \%$ in $\mathrm{W}$ the farm. In 2019 the maximum rate of increase recorded in the D5 drilling (31.56\%) and a strong decrease in the $\mathrm{W}$ the farm $(15.71 \%)$.

\section{Major elements}

\section{Calcium $\left(\mathrm{Ca}^{+2}\right)$}

Calcium is generally the dominant element in drinking water, and its content varies mainly depending on the nature of the terrain crossed (limestone or gypsum soil) (BRGM 2006). The calcium contents of the controlled waters report that the values obtained vary from $42 \mathrm{mg} / 1$ up to $77 \mathrm{mg}$ $/ 1$ in the Mougheul region (Table 6); in comparison with the WHO standard, we find that our samples are in WHO
Table 4 EC $(\mu \mathrm{S} / \mathrm{cm})$ values of water points in the Mougheul area (2009-2019)

\begin{tabular}{|c|c|c|c|c|c|c|c|}
\hline years & D1 & D2 & D3 & D4 & D5 & W6 & $\mathrm{W}$ the farm \\
\hline 2009 & 624 & 578 & 641 & 582 & 553 & 1142 & 643 \\
\hline 2010 & 621 & 579 & 649 & 592 & 550 & 1151 & 645 \\
\hline 2011 & 610 & 587 & 683 & 615 & 620 & 1163 & 658 \\
\hline 2012 & 604 & 612 & 679 & 620 & 631 & 1176 & 646 \\
\hline 2013 & 598 & 663 & 687 & 637 & 633 & 1187 & 624 \\
\hline 2014 & 588 & 645 & 651 & 642 & 644 & 1169 & 621 \\
\hline 2015 & 566 & 628 & 606 & 646 & 666 & 1182 & 584 \\
\hline 2016 & 534 & 607 & 561 & 655 & 683 & 1198 & 543 \\
\hline 2017 & 550 & 640 & 593 & 652 & 691 & 1187 & 544 \\
\hline 2018 & 586 & 661 & 611 & 658 & 696 & 1158 & 522 \\
\hline 2019 & 630 & 682 & 647 & 662 & 700 & 1160 & 552 \\
\hline
\end{tabular}


Table 5 TDS (mg/l) values of water points in the Mougheul area (2009-2019)

\begin{tabular}{llllllll}
\hline Years & D1 & D2 & D3 & D4 & D5 & W6 & W the farm \\
\hline 2009 & 466.00 & 438.00 & 472.80 & 440.50 & 408.00 & 819.56 & 487.53 \\
2010 & 463.00 & 438.40 & 489.00 & 452.00 & 409.00 & 826.80 & 485.00 \\
2011 & 461.92 & 444.00 & 517.29 & 469.80 & 465.00 & 838.66 & 491.00 \\
2012 & 459.20 & 466.00 & 517.80 & 473.80 & 471.50 & 849.50 & 481.00 \\
2013 & 457.80 & 517.20 & 525.00 & 483.70 & 469.30 & 858.80 & 466.00 \\
2014 & 447.00 & 502.00 & 492.90 & 488.50 & 481.00 & 846.00 & 462.50 \\
2015 & 435.40 & 482.50 & 454.00 & 495.80 & 504.00 & 865.50 & 435.00 \\
2016 & 402.53 & 450.46 & 418.30 & 504.40 & 518.50 & 885.00 & 404.00 \\
2017 & 423.00 & 481.00 & 449.10 & 497.90 & 527.50 & 86.00 & 406.30 \\
2018 & 441.50 & 504.60 & 464.09 & 500.40 & 531.70 & 834.00 & 410.50 \\
2019 & 469.85 & 528.70 & 483.24 & 502.37 & 536.80 & 831.02 & 410.90 \\
\hline
\end{tabular}

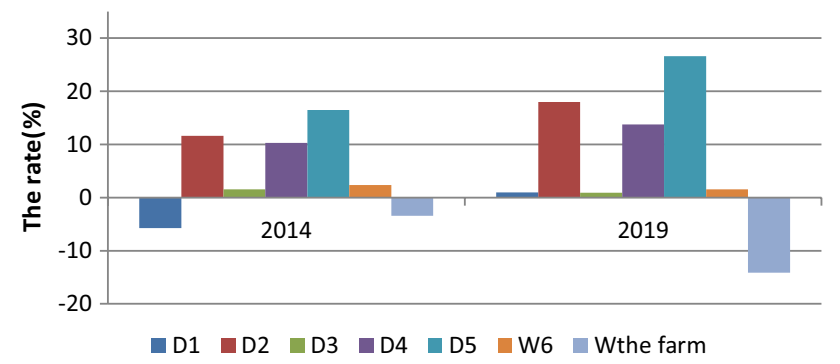

Fig. 7 The rate of change in TDS between 2014 and 2019

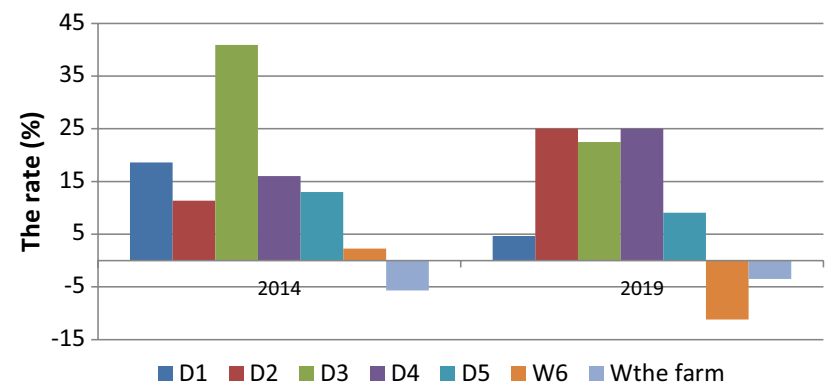

Fig. 8 The rate of change in $\mathrm{Ca}^{+2}$ between 2014 and 2019 standards (200 mg / l) for drinking water and those intended for agricultural activities.

From the Fig. 8 it shows that in 2014 the rate of increase in calcium reached $40.9 \%$ in drilling D3 and a decrease of $5.7 \%$ in W the farm. In 2019 the maximum rate of increase recorded in the D4 and D2 drilling (25\%) and a strong decrease in the $\mathrm{W}$ the farm $(11.22 \%)$.

\section{Magnesium $\left(\mathrm{Mg}^{+2}\right)$}

It is an element that often accompanies calcium and comes from the dissolution of dolomites, dolomitic limestones, and ferromagnesian minerals (BRGM 2006). The magnesium contents in de Mougheul vary between 27 and $87.6 \mathrm{mg} / 1$ (Table 7). The high values in the waters of the aquifer of the alluvial terraces can be due to the presence of magnesian clay lentils. This means that these drinking water supply results are below the thresholds of its own standard designated by the WHO $(150 \mathrm{mg} / \mathrm{l})$.

According to Fig. 9 we note that in 2014 the rate of increase in magnesium reached $92,59 \%$ in drilling D5 and a decrease of $29.62 \%$ in D1. In 2019 the maximum rate of increase recorded in the D5 drilling (109.62\%) and a strong decrease in the drilling D4 (40.73\%).
Table 6 Calcium $(\mathrm{mg} / \mathrm{l})$ values of water points in the Mougheul area (2009-2019)

\begin{tabular}{llllllll}
\hline Years & D1 & D2 & D3 & D4 & D5 & W6 & W the farm \\
\hline 2009 & 43.00 & 44.00 & 44.00 & 48.00 & 44.00 & 74.30 & 45.60 \\
2010 & 43.00 & 42.00 & 48.00 & 50.00 & 45.00 & 75.00 & 48.00 \\
2011 & 48.00 & 43.00 & 53.00 & 51.00 & 47.00 & 76.50 & 50.20 \\
2012 & 49.00 & 45.00 & 58.00 & 52.00 & 51.00 & 76.00 & 50.00 \\
2013 & 50.00 & 48.60 & 66.30 & 53.00 & 50.00 & 75.60 & 43.00 \\
2014 & 51.00 & 49.00 & 62.00 & 56.00 & 50.00 & 76.00 & 43.00 \\
2015 & 48.00 & 49.00 & 59.00 & 62.00 & 51.00 & 56.00 & 42.00 \\
2016 & 44.00 & 50.00 & 44.00 & 66.00 & 52.00 & 77.00 & 43.00 \\
2017 & 46.00 & 51.00 & 50.00 & 61.00 & 51.00 & 76.00 & 44.00 \\
2018 & 49.00 & 53.00 & 51.00 & 60.00 & 50.00 & 74.00 & 45.00 \\
2019 & 45.00 & 55.00 & 53.90 & 60.00 & 48.00 & 65.96 & 44.00 \\
\hline
\end{tabular}


Table 7 Magnesium (mg/l) values of water points in the Mougheul area (2009-2019)

\begin{tabular}{llllllll}
\hline Years & D1 & D2 & D3 & D4 & D5 & W6 & W the farm \\
\hline 2009 & 54.00 & 41.00 & 55.00 & 41.00 & 27.00 & 83.60 & 50.63 \\
2010 & 53.00 & 43.00 & 49.50 & 40.00 & 35.00 & 85.00 & 50.00 \\
2011 & 45.00 & 45.00 & 49.00 & 42.30 & 48.00 & 85.40 & 49.60 \\
2012 & 43.00 & 46.00 & 45.00 & 43.00 & 49.00 & 86.00 & 51.00 \\
2013 & 40.00 & 49.00 & 42.00 & 45.00 & 50.00 & 88.70 & 54.00 \\
2014 & 38.00 & 45.00 & 40.00 & 45.00 & 52.00 & 87.00 & 49.00 \\
2015 & 30.00 & 42.00 & 38.00 & 40.00 & 54.00 & 86.00 & 39.00 \\
2016 & 28.00 & 40.00 & 35.00 & 38.60 & 57.00 & 85.00 & 31.00 \\
2017 & 30.00 & 46.00 & 36.00 & 41.00 & 56.50 & 86.00 & 30.00 \\
2018 & 40.00 & 47.00 & 38.00 & 42.00 & 56.60 & 85.00 & 31.00 \\
2019 & 48.00 & 47.30 & 39.00 & 42.30 & 56.60 & 87.60 & 32.00 \\
\hline
\end{tabular}

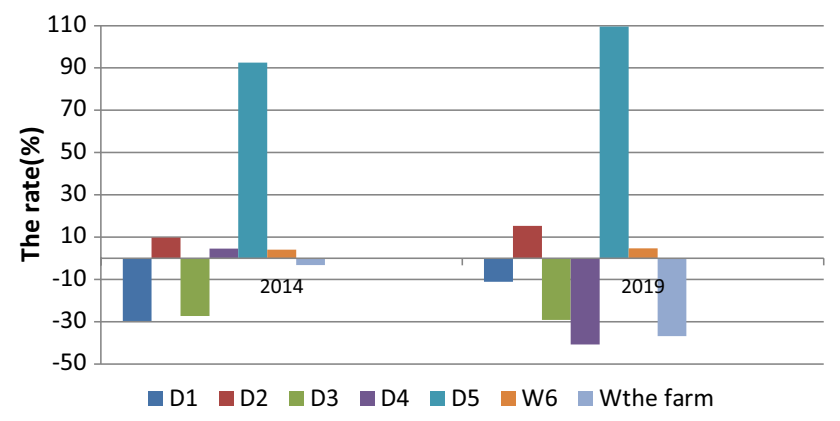

Fig.9 The rate of change in $\mathrm{Mg}^{+2}$ between 2014 and 2019

\section{Potassium $\left(\mathrm{K}^{+}\right)$}

It is an alkaline element, very reactive with water, and it is found in igneous rocks and in nature in the form of double chloride in many ores (BRGM 2006). The potassium concentration of Mougheul groundwater varies between 1 and $5 \mathrm{mg} / 1$ (Table 8). In all years, the samples give potassium results below the threshold of the WHO standard (12 mg / 1).
Figure 10 shows that in 2014 the rate of increase in potassium reached $90 \%$ in drilling D3 and a decrease of $23.3 \%$ in drilling D5. In 2019 the maximum rate of increase recorded in $\mathrm{W}$ the farm $(110 \%)$ and a strong decrease in the well W6 $(27.58 \%)$.

\section{Sodium $\left(\mathrm{Na}^{+}\right)$}

Sodium represents the least abundant cation in the waters of the Mougheul aquifer, and the contents are between 7 and $21 \mathrm{mg} / 1$ except the well of W6 which varies between 40 and $56 \mathrm{mg} / 1$ (Table 9). In all samples the sodium results are below the threshold of the WHO standard (250 mg / 1).

According to Fig. 11 we note that in 2014 the rate of increase in sodium reached $85.71 \%$ in D1 drilling and a decrease of 55\% in D5 drilling. In 2019 the maximum rate of increase recorded in D2 drilling (104.28\%) and a strong decrease in $\mathrm{W}$ the farm $(132.55 \%)$.
Table 8 Potassium (mg/l) values of water points in the Mougheul area (2009-2019)

\begin{tabular}{llllllll}
\hline Years & D1 & D2 & D3 & D4 & D5 & W6 & W the farm \\
\hline 2009 & 1.00 & 1.00 & 1.00 & 1.50 & 2.60 & 2.90 & 1.00 \\
2010 & 2.00 & 1.50 & 1.50 & 2.00 & 2.00 & 2.80 & 2.00 \\
2011 & 1.00 & 1.00 & 1.80 & 2.60 & 1.00 & 2.60 & 2.30 \\
2012 & 2.00 & 1.50 & 1.80 & 2.80 & 1.50 & 2.50 & 2.00 \\
2013 & 2.00 & 1.00 & 1.90 & 2.90 & 2.00 & 2.30 & 1.00 \\
2014 & 1.00 & 1.00 & 1.90 & 2.50 & 2.00 & 3.00 & 1.50 \\
2015 & 1.90 & 1.50 & 2.00 & 2.30 & 1.50 & 3.50 & 2.00 \\
2016 & 2.00 & 2.00 & 2.30 & 2.00 & 1.00 & 5.00 & 2.00 \\
2017 & 2.00 & 2.00 & 2.10 & 2.00 & 2.00 & 4.00 & 2.10 \\
2018 & 1.50 & 1.50 & 2.09 & 2.90 & 2.10 & 3.00 & 2.00 \\
2019 & 2.00 & 2.00 & 2.08 & 1.90 & 2.30 & 2.10 & 2.10
\end{tabular}




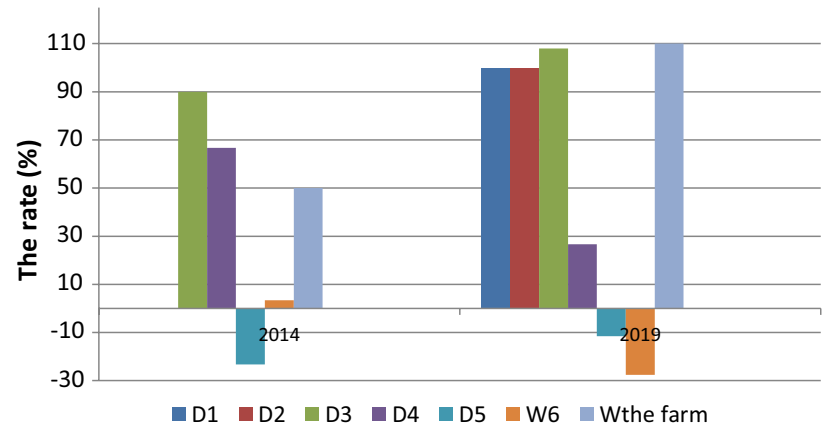

Fig.10 The rate of change in $\mathrm{K}^{+}$between 2014 and 2019

\section{Chlorides $\left(\mathrm{Cl}^{-}\right)$}

Chloride in the form of chloride ion $\left(\mathrm{Cl}^{-}\right)$is the major inorganic anion present in water and wastewater (Thakur et al 2015). Chlorides can have several origins and are mainly linked to the dissolution of salt fields. The dissolution of these salts is very easy hence their presence in high concentrations in the waters having crossed the clay-sandy or clayey formations. Thus, they can also come from human action from highway relief or by contamination by wastewater (BRGM 2006). Chlorides give an unpleasant taste and pose the problem of corrosion in pipes and tanks from $500 \mathrm{mg} / 1$ (WHO standard). The chlorides contents vary between 13 and $30 \mathrm{mg} / 1$ in all the drilling of Mougheul except that well W6 year 2016 which can wait for the value $97 \mathrm{mg} / \mathrm{l}$ (Table 10).

From Fig. 12 it shows that in 2014 the rate of increase in chlorides reached $38,88 \%$ in drilling D4 and a decrease of $36.36 \%$ in drilling D1. In 2019 the maximum rate of increase recorded in the D4 drilling (53.33\%) and a strong decrease in the $\mathrm{W}$ the farm $(44.9 \%)$.
Bicarbonate $\mathrm{HCO}_{3}^{-}$

Bicarbonates are found in natural waters, and their presence in water is due to the dissolution of carbonate formations such as limestones and dolomites (Drever 2001). $\mathrm{HCO}_{3}{ }^{-}$is the most common anion of groundwater, basically derived from soil carbon dioxide (CO2) (Yammani et al. 2008).

The bicarbonate content varies from 199 to $339 \mathrm{mg} / 1$ (Table 11) in the water points of Mougheul, and their origin is due to the leaching of the carbonate formations.

Figure 13 shows that in 2014 the rate of increase in bicarbonates reached $28.2 \%$ in drilling D5 and a decrease of $8.1 \%$ in $\mathrm{W}$ the farm. In 2019 the maximum rate of increase recorded in the D5 drilling (48.71\%) and a strong decrease in the $\mathrm{W}$ the farm $(22.77 \%)$.

\section{Sulfates $\mathrm{SO}_{4}{ }^{-2}$}

They are present in natural waters at very variable levels, and they can come from the dissolution of gypsum. The latter can be triassic, as it can be associated with more recent formations such as Mio-Plio-Quaternary clays. They also depend on industrial waste. Sulfates are very soluble and also very stable elements (BRGM 2006). The contents vary between 54 and $86 \mathrm{mg} / \mathrm{l}$ in all the water points except W6 which gives high values between 170 and $196 \mathrm{mg} / \mathrm{l}$ (Table 12) and probably come from the

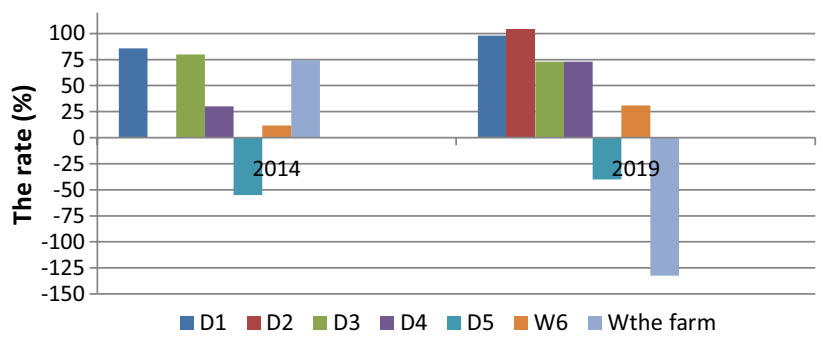

Fig. 11 The rate of change in $\mathrm{Na}^{+}$between 2014 and 2019
Table 9 Sodium (mg/l) values of water points in the Mougheul area (2009-2019)

\begin{tabular}{lrlllllr}
\hline Years & D1 & D2 & D3 & D4 & D5 & W6 & W the farm \\
\hline 2009 & 7.00 & 12.00 & 10.00 & 10.00 & 20.00 & 43.00 & 8.60 \\
2010 & 8.00 & 11.00 & 14.00 & 11.00 & 10.00 & 45.00 & 9.00 \\
2011 & 10.62 & 10.00 & 16.30 & 13.00 & 9.00 & 47.30 & 12.00 \\
2012 & 11.00 & 11.50 & 17.00 & 12.00 & 9.00 & 50.00 & 11.00 \\
2013 & 12.00 & 12.30 & 18.60 & 12.96 & 9.00 & 50.30 & 7.00 \\
2014 & 13.00 & 12.00 & 18.00 & 13.00 & 9.00 & 48.00 & 15.00 \\
2015 & 18.00 & 11.00 & 17.50 & 13.50 & 10.00 & 46.00 & 20.00 \\
2016 & 19.00 & 11.86 & 17.00 & 14.00 & 10.00 & 44.00 & 21.00 \\
2017 & 15.00 & 12.00 & 17.00 & 15.00 & 11.00 & 49.00 & 20.00 \\
2018 & 13.00 & 13.00 & 17.10 & 16.00 & 11.50 & 50.00 & 21.00 \\
2019 & 13.86 & 14.30 & 17.30 & 17.30 & 12.00 & 56.30 & 20.00 \\
\hline
\end{tabular}


Table 10 Chloride (mg/l) values of water points in the Mougheul area (2009-2019)

\begin{tabular}{llllllll}
\hline Years & D1 & D2 & D3 & D4 & D5 & W6 & W the farm \\
\hline 2009 & 22.00 & 20.00 & 28.00 & 18.00 & 30.00 & 89.60 & 26.50 \\
2010 & 20.00 & 20.00 & 26.00 & 20.00 & 20.00 & 87.00 & 27.00 \\
2011 & 16.30 & 19.00 & 25.33 & 24.36 & 17.00 & 84.56 & 28.30 \\
2012 & 15.90 & 20.00 & 24.00 & 24.00 & 20.00 & 84.00 & 25.00 \\
2013 & 14.50 & 23.30 & 22.69 & 25.30 & 25.00 & 83.60 & 22.00 \\
2014 & 14.00 & 24.00 & 21.00 & 25.00 & 24.00 & 85.00 & 20.00 \\
2015 & 13.50 & 28.00 & 19.00 & 26.00 & 24.50 & 90.00 & 18.00 \\
2016 & 13.00 & 30.00 & 16.80 & 26.53 & 24.60 & 97.00 & 13.00 \\
2017 & 13.50 & 29.00 & 18.00 & 26.90 & 25.00 & 92.00 & 14.20 \\
2018 & 14.00 & 28.00 & 19.00 & 27.00 & 25.50 & 88.00 & 14.50 \\
2019 & 15.00 & 27.00 & 20.30 & 27.42 & 26.30 & 85.60 & 14.60 \\
\hline
\end{tabular}

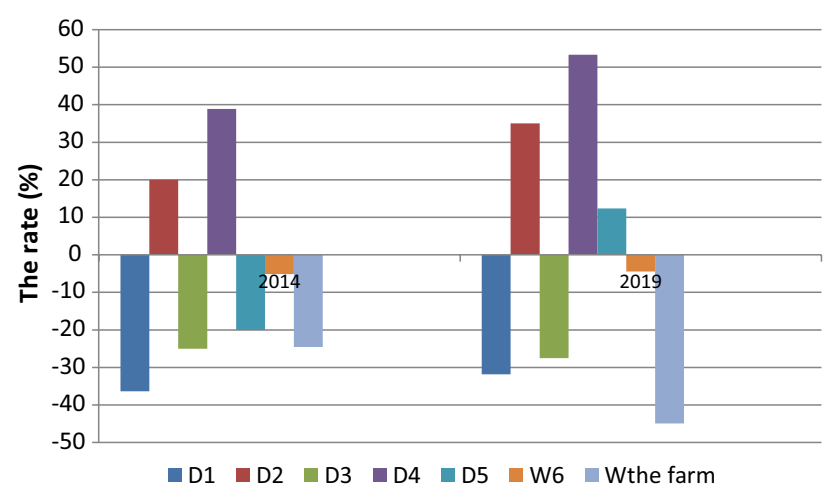

Fig. 12 The rate of change in $\mathrm{Cl}^{-}$between 2014 and 2019

leaching of the gypsum represented in the form of lenses in the quaternary formations as well as the presence marls and clays in these formations. The concentration of sulfate is close to react with human organs if the value exceeds the maximum allowable limit of $400 \mathrm{mg} / \mathrm{l}$ (WHO 1993) and causes a laxative effect on human system with the excess magnesium in groundwater (Jacintha et al. 2016).
Figure 14 shows that in 2014 the rate of increase in sulfate reached $30 \%$ in drilling D5 and a decrease of $15.15 \%$ in drilling D4. In 2019 the maximum rate of increase recorded in drilling D5 (36.22\%) and a strong decrease in the drilling D4 $(9.39 \%)$.

\section{Nitrates $\mathrm{NO}^{-}$}

It is a very soluble form, and its presence in water is linked to fertilizers, and nitrate ion $\left(\mathrm{NO}^{-}\right)$is the most oxidized form of nitrogen. Nitrate in groundwater may result from point sources such as sewage disposal systems and livestock facilities, non-point sources such as fertilized agricultural lands, parks or naturally occurring sources of nitrogen (Jay Krishna Thakur et al, 2015). The presence of nitrates in the waters of the Mougheul aquifer is an indication of pollution of domestic origin (discharge of wastewater into valley Mougheul). The nitrate contents are between 5.8 and $32.5 \mathrm{mg} / 1$ (Table 13), and high values have been observed at drilling level W6 which exceeds the limits recommended by the WHO (50 $\mathrm{mg} / \mathrm{l})$.

According to Fig. 15 we note a strong increase in the rate of nitrate at the level of drilling D3 in 2014 (382.75\%) and
Table 11 Bicarbonate $(\mathrm{mg} / \mathrm{l})$ values of water points in the Mougheul area (2009-2019)

\begin{tabular}{llllllll}
\hline Years & D1 & D2 & D3 & D4 & D5 & W6 & W the farm \\
\hline 2009 & 247.00 & 235.00 & 247.00 & 232.00 & 195.00 & 280.00 & 259.00 \\
2010 & 241.00 & 235.90 & 260.00 & 245.00 & 200.00 & 282.00 & 252.00 \\
2011 & 239.00 & 238.00 & 265.00 & 258.60 & 232.00 & 287.00 & 250.00 \\
2012 & 240.00 & 250.00 & 266.00 & 260.00 & 238.00 & 290.00 & 248.00 \\
2013 & 241.00 & 289.00 & 267.39 & 260.00 & 240.00 & 296.00 & 247.00 \\
2014 & 230.00 & 278.00 & 250.00 & 265.00 & 250.00 & 300.00 & 238.00 \\
2015 & 225.00 & 260.00 & 230.00 & 268.00 & 270.00 & 320.00 & 220.00 \\
2016 & 201.00 & 225.00 & 209.00 & 270.00 & 280.00 & 339.00 & 198.00 \\
2017 & 220.00 & 250.00 & 230.00 & 265.00 & 285.00 & 320.00 & 199.00 \\
2018 & 225.00 & 270.00 & 240.00 & 264.00 & 287.00 & 295.00 & 200.00 \\
2019 & 230.00 & 290.00 & 250.00 & 264.00 & 290.00 & 289.56 & 200.00
\end{tabular}




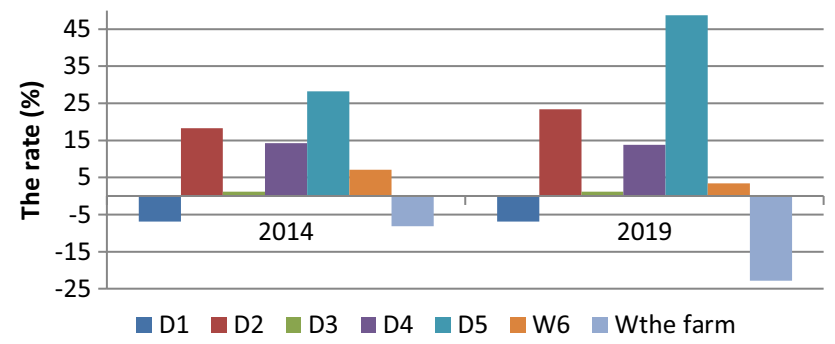

Fig. 13 The rate of change in $\mathrm{HCO}_{3}{ }^{-}$between 2014 and 2019
(345.86\%) in 2019 by contribution 2009 and a decrease of $45.57 \%$ (2014) and $25.17 \%$ (2019) in drilling D5.

\section{Conclusion}

This study was conducted to give the qualitative evolution of groundwater in the Mougheul area during the period 2009-2019, in order to assess its quality for drinking water supply and irrigation. The need for this research is due to the problems facing the region such as drought, over-
Table 12 Sulfate $(\mathrm{mg} / \mathrm{l})$ values of water points in the Mougheul area (2009-2019)

\begin{tabular}{llllllll}
\hline Years & D1 & D2 & D3 & D4 & D5 & W6 & W the farm \\
\hline 2009 & 80.00 & 60.00 & 82.00 & 66.00 & 60.00 & 186.30 & 80.60 \\
2010 & 76.00 & 58.00 & 80.00 & 60.00 & 70.00 & 188.00 & 80.00 \\
2011 & 79.00 & 60.00 & 77.56 & 54.00 & 86.00 & 190.00 & 79.60 \\
2012 & 77.30 & 65.00 & 75.00 & 55.00 & 83.00 & 195.00 & 79.00 \\
2013 & 76.00 & 67.20 & 73.62 & 57.00 & 79.00 & 196.00 & 80.00 \\
2014 & 77.00 & 67.00 & 72.00 & 56.00 & 78.00 & 180.00 & 78.00 \\
2015 & 79.00 & 66.00 & 73.00 & 57.00 & 76.00 & 175.00 & 75.00 \\
2016 & 80.00 & 66.00 & 75.60 & 58.63 & 75.60 & 170.00 & 75.00 \\
2017 & 80.00 & 65.00 & 75.00 & 59.00 & 77.00 & 172.00 & 75.00 \\
2018 & 81.00 & 65.10 & 73.90 & 59.50 & 78.00 & 174.00 & 74.00 \\
2019 & 83.00 & 65.30 & 74.80 & 59.80 & 79.60 & 178.60 & 74.63 \\
\hline
\end{tabular}

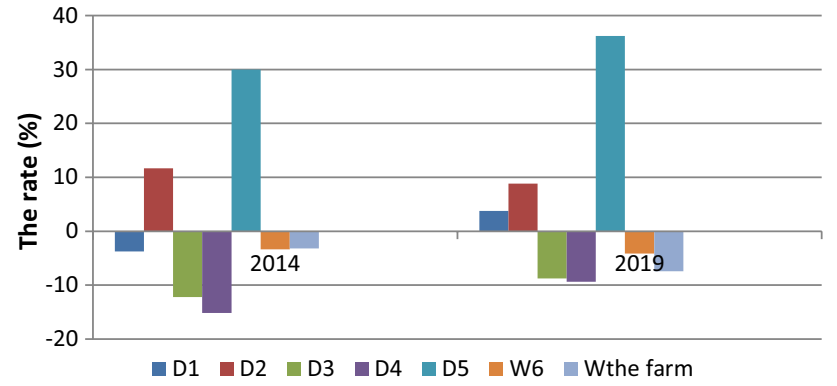

Fig. 14 The rate of change in $\mathrm{SO}_{4}{ }^{-2}$ between 2014 and 2019 exploitation of groundwater, unavailability of surface water, and the high demand for water resulting from agricultural activities. The physicochemical study of the groundwater of Mougheul shows that: According to the diagram of Schöeller and Berkaloff, we have observed that the groundwater has the bicarbonate calcium and bicarbonate magnesium facies. The representation of the data on the triangular Piper diagram of the companions 2009 and 2019 shows that the well of W6 has the facies chlorinated and calcium and magnesium sulfate. The other water points have the bicarbonate calcium and magnesium facies. The total dissolved salt content (TDS) can classify the groundwater of the study region
Table 13 Nitrate $(\mathrm{mg} / \mathrm{l})$ values of water points in the Mougheul area (2009-2019)

\begin{tabular}{llllllll}
\hline Years & D1 & D2 & D3 & D4 & D5 & W6 & W the farm \\
\hline 2009 & 12.00 & 25.00 & 5.80 & 24.00 & 29.40 & 59.86 & 15.60 \\
2010 & 20.00 & 27.00 & 10.00 & 24.00 & 27.00 & 62.00 & 17.00 \\
2011 & 23.00 & 28.00 & 29.30 & 23.54 & 25.00 & 65.30 & 19.00 \\
2012 & 21.00 & 27.00 & 31.00 & 25.00 & 20.00 & 66.00 & 15.00 \\
2013 & 22.30 & 26.80 & 32.50 & 27.56 & 14.30 & 66.30 & 12.00 \\
2014 & 23.00 & 26.00 & 28.00 & 26.00 & 16.00 & 67.00 & 18.00 \\
2015 & 20.00 & 25.00 & 20.00 & 27.00 & 17.00 & 68.00 & 19.00 \\
2016 & 15.53 & 25.60 & 18.60 & 28.64 & 18.30 & 68.00 & 21.00 \\
2017 & 16.50 & 26.00 & 21.00 & 28.00 & 20.00 & 67.00 & 22.00 \\
2018 & 18.00 & 27.00 & 23.00 & 29.00 & 21.00 & 65.00 & 23.00 \\
2019 & 20.35 & 27.80 & 25.86 & 29.65 & 22.00 & 65.30 & 23.60 \\
\hline
\end{tabular}


Fig. 15 The rate of change in $\mathrm{NO}_{3}{ }^{-}$between 2014 and 2019

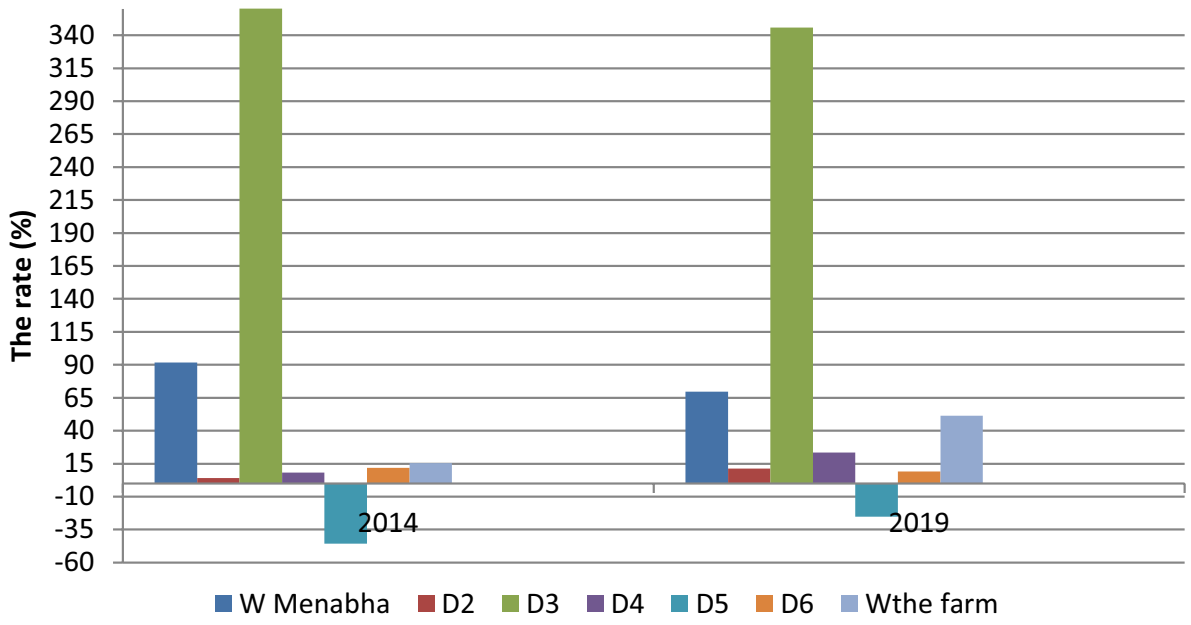

References

in almost fresh water. The $\mathrm{pH}$ values generally reflect the alkaline nature of the groundwater of Mougheul area. SAR values show that the waters of the Mougheul aquifer are excellent for irrigation. The classification according to the Wilcox diagram shows that the groundwater of Mougheul is good quality, except that the W6 is suitable for irrigation and needs to control the evolution of salinity. The groundwater remains drinkable during the period 2009-2019, according to the drinking water standards of the WHO. The origin of nitrates in the waters of the Mougheul aquifer is domestic (discharge of wastewater into valley the Mougheul).

Acknowledgements The authors would like to express their gratitude to the MESRS of Algeria, for the support.

Funding This study was funded by author.

\section{Compliance with ethical standards}

Conflict of interest The authors declare that they have no conflict of interest.

Open Access This article is licensed under a Creative Commons Attribution 4.0 International License, which permits use, sharing, adaptation, distribution and reproduction in any medium or format, as long as you give appropriate credit to the original author(s) and the source, provide a link to the Creative Commons licence, and indicate if changes were made. The images or other third party material in this article are included in the article's Creative Commons licence, unless indicated otherwise in a credit line to the material. If material is not included in the article's Creative Commons licence and your intended use is not permitted by statutory regulation or exceeds the permitted use, you will need to obtain permission directly from the copyright holder. To view a copy of this licence, visit http://creativecommons.org/licenses/by/4.0/.
Agence Nationale Des Ressources Hydrauliques (2008) Synthèse sur les eaux souterraines de la région nord et est de la wilaya de Béchar. Direction régionale sud ouest Adrar.

Appelo CAJ, Postma D (1993) «Geochemistry, Groundwater and Pollution». xvi $+536 \mathrm{pp}$

Back W, Hanshaw B (1965) Chemical geohydrology. In: Chow VT (ed) Advances in hydroscience, vol 2. Academic Press Inc, New York, pp 49-109

Batram J. \& Ballance R (1999), Water quality monitoring : a practical guide to the design and implementation of freshwater quality studies and monitoring programs

BRGM (2006), Guides techniques, qualité des eaux souterraines. Méthodes de caractérisation des états de références des aquifères français, France

Chabane S, Amri K, Hamdidouche R (2019) Deformation pattern in the El Ahmar area (Bechar Basin Southwestern Algeria): contribution of Lansat $8 \mathrm{OLI}$ and field measurement. Arabian J Geosci 12:158

Deleau P (1952) Alimentation de Colomb-Béchar, SERV. Géol. Algérie, Trav. Réc. Coll.III

Domenico PA, Schwartz S (1997) Physical and chemical hydrogeology. John Wiley \& Sons, New York, p 528

Drever I (2001) The geochemistry of natural waters: Surface and groundwater environments. Prentice Hall Publishers, New Jersey, p 436

Gleick PH (2000) A look at twenty-first century water resources development. Water Int 25(1):127-138

IDROTECNECO, (1979) Etude hydrogéologique de la région de Bechar. Rapport interne, DHWB. $170 \mathrm{p}$

Jacintha TGA, Rawat KS, Mishra A, Singh SK (2017) Hydrogeochemical characterization of groundwater of peninsular Indian region using multivariate statistical techniques. Appl Water Sci 7:30013013. https://doi.org/10.1007/s13201-016-0400-9

Kendouci MA, Kharroubi B, Mebarki S, Bendida A (2016) Physicochemical quality of groundwater and pollution risk in arid areas: the case of Algerian Sahara. Arab J Geosci 9:146

Kendouci MA, Bendida A, Mebarki S, Kharroubi B (2019) Study of the management efficiency of the drinking water supply in arid areas: case of Bechar city (southwest of Algeria). Appl Water Sci $9(8)$

MEBARKI S (2013) Hydrogeological characterization of the Jurassic aquifer in the Mougheul plain. (North Ksour, BECHAR), Memory of Magisterium, University of Bechar, p 61 
Mekkaoui A (2000) Border of the Atlas furrow and Saharan platform. Lower and middle Jurassic. (Southern Grouz, Charef-Fendi, Algeria South West), memoir of Magister, University of Oran, P110-116.

Nemčić-Juree J, Singh SK, Jazbee A (2017) Hydrochemical investigations of groundwater quality for drinking and irrigational purposes: two case studies of Koprivnica-Kriz ${ }^{`}$ evci County (Croatia) and district Allahabad (India). Sustain Water Resour Manag. https ://doi.org/10.1007/s40899-017-0200-x

Nedjari A, Ait Ouali R, Delfaud J (2002) The Triassic of the Algerian Atlasic and Saharian basins : check point and new approach ]. In: Stratigraphie de l'Algérie : Contributions et mises au point; CSA, SGA (Eds)., Mémoires du Service Géologique de l'Algérie vol 11, pp 87-113.

Rawat KS, Mishra AK, Sehgal VK, Tripathi VK (2012) Spatial variability of ground water quality in Mathura district (Uttar Pradesh, India) with geostatistical method. Int J Remote Sens Appl 2(1):1-9

Rawat KS, Mishra AK, Sehgal VK, Tripathi VK (2013) Identification of geospatial variability of fluoride contamination in ground water of Mathura District, Uttar Pradesh, India. J Appl Nat Sci 4(1):117-122

Rawat KS, German Amali Jacintha T, Singh SK (2018) Hydro-chemical survey and quantifying spatial variations in groundwater quality in coastal region of Chennai, Tamilnadu, India - a case study. Indones J Geogr 50(1):57-69

Roche MA, (1973), Hydrogéologie de la haute Saoura (Sahara Nord Occidental). CNRS (Recherche sur les zones arides), France, 1973, 91p.

RODIER J (2009), L'analyse de l'eau, Dunod, Parie, Edition 9, 2009, P1438.

Rodier J (1996) The analysis of the Water: Natural water, Waste Water, Sea Water, eighth ed., Dunod, Paris

Sharma B, Kumar M, Denis DM, Singh SK (2018) Appraisal of river water quality using open-access earth observation data set: a study of river Ganga at Allahabad (India). Sustain Water Res Manag. https://doi.org/10.1007/s40899-018-0251-7

Singh KP, Malik A, Mohan D, Singh VK, Sinha S (2006) Evaluation of groundwater quality in northern Indo-Gangetic alluvium region. Environ Monit Assess 112:211-230

Singh SK, Mustak S, Srivastava PK, Szabó S, Islam T (2015) Predicting spatial and decadal LULC changes through cellular automata
Markov chain models using earth observation datasets and geoinformation. Environ Process 2:61-78

Singh S, Srivastava PK, Gupta M, Mukherjee S (2012) Modeling mineral phase change chemistry of groundwater in a rural-urban fringe. Water Sci Technol 66(7):1502-1510

Srivastava PK, Mukherjee S, Gupta M (2008) Groundwater quality assessment and its relation to land use/land cover using remote sensing and GIS. In: Proceedings of international groundwater conference on groundwater use- efficiency and sustainability: groundwater and drinking water issues, Jaipur, India, pp19-22.

Srivastava PK, Han D, Gupta M, Mukherjee S (2012) Integrated framework for monitoring groundwater pollution using a geographical information system and multivariate analysis. Hydrl Sci J 57(7):1453-1472

Sun H, Bergstrom JC, Dorfman JH (1992) Estimating the benefits of groundwater contamination control. South J Agric Econ 24:63

Thakur JK, Singh P, Singh SK, Bhaghel B (2013) Geochemical modelling of fluoride concentration in hard rock terrain of Madhya Pradesh, India. Acta Geol Sin 87:1421-1433. https://doi. org/10.1111/1755-6724.12139

Thakur JK, Diwakar J, Singh SK (2015) Hydrogeochemical evaluation of groundwater of Bhaktapur Municipality, Nepal. Environ Earth Sci 74:4973-4988

World Health Organization (WHO) (1993) Guidelines for drinking water quality. 2nd edn, vol 1-3, World Health Organization, Geneva

WILCOX LV (1955), Classification and use of irrigation waters, vol 969. U.S. Department of Agriculture Circular, Washington, DC, 1955, p 19

Yammani SR, Reddy TVK, Reddy MRK (2008) Identification of influencing factors for groundwater quality variation using multivariate analysis. Environ Geol 55:9-16

Zerrouki A (1993) Etude des affleurements du Précambrien Deux (P II) du Nord de Béchar. Bulletin du Service Géologique de l'Algérie 4(2):89-97

Publisher's Note Springer Nature remains neutral with regard to jurisdictional claims in published maps and institutional affiliations. 